\title{
DEVELOPING POP-UP BOOK MEDIA IN EARLY READING AT LOW CLASS
}

\author{
Suci Oktaviana \\ Universitas Riau, Pekanbaru, Indonesia \\ sucioktaviana58@gmail.com
}

\begin{abstract}
This research was motivated by the lack of media in early reading at the low class. Pop-up book was a media that provided a more attractive visualization for students. Pop-up books provoked students' enthusiasm in reading and stimulated students' imagination. This type of research was development $(R \& D)$, using the ADDIE model consisting of 5 stages, namely analysis, design, development, implementation, evaluation. The data were obtained from the questionnaire filled in by validators and field experts viewed from 5 aspects, namely simplicity, emphasis, balance, integration, and media design. Then, the feasibility test by media experts obtained a percentage of $89.55 \%$ (very feasible), by material experts was $88.55 \%$ (very feasible), and by field experts on media design was $86.25 \%$ (very feasible), and on the material was $85.4 \%$ (very feasible). Overall, pop-up book media for early reading was very feasible.
\end{abstract}

Keywords: pop-up book, early reading

\section{PENGEMBANGAN MEDIA POP-UP BOOK DALAM MEMBACA PERMULAAN DI KELAS RENDAH}

\begin{abstract}
ABSTRAK
Penelitian ini dilatar belakangi karena kurangnya media dalam mebaca permulaan di kelasrendah. Pop-up book merupakan media yang dapat memberikan visualisasi yang lebih menarik bagi siswa. Pop-up book dapat memancing keantusiasan siswa dalam membaca. Serta dapat merangsang imajinasi siswa. Jenis penelitian ini adalah pengembangan (Research and Development), menggunakan model EDDIE yang terdiri dari 5 tahapan yaitu analisis, perancangan, pengembangan, pelaksanaan, penilaian. Data yang diperoleh dari kusioner yang di isi oleh validator dan ahli lapangan yang di lihat dari 5 aspek yaitu kesederhanaan, penekanan, keseimbangan,keterpaduan, dan desain media. Pada uji kelayakan oleh ahli media memperoleh presentase $89.55 \%$ (sangat layak), ahli materi $88.55 \%$ (sangat layak), dan ahli dilapangan pada desain media $86.25 \%$ (sangat layak), pada materi $85.4 \%$ (sangat layak). Secara keseluruham pengembangan media pop-up book dalam membaca permulaan di kelas rendah dapat dikatakan sangat layak.
\end{abstract}

Kata Kunci: pop-up book, membaca permulaan

\begin{tabular}{|c|c|c|}
\hline Submitted & Accepted & Published \\
\hline 19 Agustus 2020 & 15 April 2021 & 16 September 2021 \\
\hline
\end{tabular}

\begin{tabular}{|l|c|c|}
\hline Citation & $:$ & $\begin{array}{c}\text { Oktaviana, S. (2021). Developing Pop-Up Book Media in Early Reading at Low Class. Jurnal PAJAR (Pendidikan dan } \\
\text { Pengajaran), 5(5), 1313-1320. DOI : http://dx.doi.org/10.33578/pjr.v5i5.8117. }\end{array}$ \\
\hline
\end{tabular}

\section{PENDAHULUAN}

Media berasal dari bahasa latin yang mana merupakan bentuk jamak dari kata medium yang secara harafiah berarti perantara atau pengantar. Dimana media merupakan perantara atau pengantar sebuah pesan atau informasi dari si pengirim kepada si penerima pesan atau informasi. Media juga merupakan sebuah bentuk komunikasi baik audiovisual maupun tercetak (sadiman, 2011). Media sendiri juga merupakan sesuatu yang dapat digunakan dalam penyalurkan pesan dari si pengirim ke si penerima pesan sehingga dapat merangsang pikiran, perasaan, perhatian, serta minat dan kemauan siswa sehingga proses belajar terjadi dalam rangka untuk mencapai tujuan pembelajaran secara efektif tentunya (Sukiman, 2012). Dalam proses pengembangan media visual terdapat ada 5 Aspek yang dapat di jadikan acuan yaitu diantaranya: kesederhanaan, keseimbangan, keterpaduan, penekanan dan desain media. (Arsyad, 2011)

Pop-up book adalah sebuah buku yang memiliki tampilan gambar yang bisa di tegakan serta membentuk objek-objek yang indah dan dapat bergerak atau memberi efek yang 
menakjubkan. Juga merupakan jenis buku atau kartu yang didalamnya terdapan lipatan gambar yang dipotong dan muncul ketika halamanya di buka (Sholikhah, 2017). Pop-up book hampir sama dengan origami, dikarenakan keduanya menggunakan teknik yang sama yaitu teknik melipat kertas. Pop-up book lebih cenderung pada pembuatan mekanis kertas yang dapat membuat gambar lebih baik dari sisi dimensinya, dimana bentuk benda yang dapat bergerak dan berdiri tegak yang disusun sealami mungkin supaya terlihat lebih menarik (Wahyudi, 2017). Pop-up book merupakan buku yang didalamnya terdapat unsur 3 dimensi (3D) dan apabila halaman bukunya dibuka gambar yang terdapat didalamnya akan berdiri tegak (Rosalina, 2018). . Dan juga menurut Khoirotun, pop-up book dianggap mempunyai daya tarik sendiri, yaitu dengan menyajikan visualisasi dengan bentuk-bentuk yang di buat dengan melipat dan sebagainya (Rahmatilah, 2017).

Membaca merupakan proses memperoleh pesan yang disampaikan oleh seorang penulis melalui tulisanya. Membaca juga merupakan proses yang dilakukan serta dipergunakan oleh pembaca untuk memperoleh pesan yang hendak disampaikan oleh penulis melalui media kata/ bahasa tulis. Juga dapat dianggap sebagai suatu proses untuk memahami sesuatu yang tersirat dalam yang tersurat, melihat pikiran yang terkandung di dalam kata-kata yang tertulis. Memaca merupakan kegiatan yang bermanfaat dan penting dalam kehidupan, banyak sekali manfaat yang didapat dari membaca daiantaranya. Membaca permulaan merupakan proses recording dan discoding. Membaca merupakan suatu proses yang bersifat fisik da psikologis. Dimana proses yang bersifat fisik berupa kegiatan mengamati tulisan secara visual. Dengan indra visual, pembaca mengenali dan membedakan gambargambar bunyi serta kombinasinya (Taufina, 2016). Membaca permulaan di sekolah dasar bertujuan untuk membangkitkan, membina dan memupuk minat anak untuk membaca. Pembelajaran membaca permulaan diberikan di kelas satu memiliki tujuan yaitu agar siswa memiliki kemampuan memahami dan menyuarakan tulisanya dengan intonasi yang wajar, sebagai dasar untuk dapat membaca lanjutan (Irdawati, 2016).

\section{METODE PENELITIAN}

Jenis penelitian yang dilakukan merupakan penelitian pengembangan dengan istilah Reseach and Development (R\&D), metode penelitian ini digunakan untuk menghasilkan suatu produk tertentu, dan menguji kelayakan atau keefektifan produk tersebut (Sugiyono, 2017). Dalam penelitian ini peneliti mengembangkan media pop up book untuk membaca permulaan. Dimana proses pengembangan ini menggunakan model pengembangan yaitu model ADDIE yang terdiri dari lima tahapanyang meliputi analisis (analyze), perencanaan (design), pengembangan (development), implementasi (implementation), dan evaluasi (evaluation).

Data hasil penelitian berupa hasil penilaian validasi oleh ahli media, ahli materi, dan 1 orang guru di sekolah dasar. Aspek penilaian yang dinilai oleh ahli dibuat menggunakan skala linkert dengan skor 1-4. Pop-up book yang di kembangkan dapat di uji cobakan jika penilaian oleh validator di kategorikan sangat layak dan layak. Validasi media ditentukan oleh nilai ratarata skor tiap aspek yang didapat dari validator dengan rumus :

$$
\text { Presentase } \frac{\text { Skor yang di peroleh }}{\text { Skor maksimum }} \times 100 \%
$$

Tabel 1. Interval Kriteria Validitas

\begin{tabular}{ccc}
\hline No & Interval rata-rata skor & Kategori Respon \\
\hline 1 & $85-100$ & Sangat Layak \\
2 & $75-84$ & Layak \\
3 & $65-74$ & Cukup Layak \\
4 & $<65$ & Kurang Layak \\
\hline
\end{tabular}




\section{HASIL DAN PEMBAHASAN \\ Deskripsi penelitian}

Penelitian ini menggunakan model pengembangan ADDIE, terdiridari 5 tahapan yaitu : analysis (analisis), design (desain), development (pengembangan), implementation (implementasi), evaluation (evaluasi). Teknik pengumpulan data pada penelitian ini yaitu dengan menggunakan kusioner yang dilakukan dengan memberikan seperangkat pernyataan tertulis kepada responden untuk di jawab sesuai dengan indikator yang berhubungan dengan pengembangan media pop-up book dalam membaca permulaan di kelas rendah. Setelah memberikan kusioner kemudian data hasil penelitian yang telah di peroleh diolah dan dijabarkan dalam bentuk uraian dan tabel. Selanjutnya dilakukan penarikan kesimpulan, penelitian mengambil kesimpulan dari data yang telas tersusun secara sistematis.

\section{Hasil Penelitian \\ Tahap Analisis \\ Analisis Kebutuhan}

Berdasarkan observasi di lapangan yang di lakukan peneliti yaitu di SDN 181 Pekanbaru, sekolah tersebut memiliki beberapa buku sebagai fasilitas untuk membaca permulaan. Dimana bukubuku tersebut berupa buku berisi teks bacaan yang di sertai gambar yang mana dapat menarik perhatian siswa untuk membaca permulaan.

\section{Analisis Karakteristik}

Berdasarkan tahap usia pengguna yang telah di kembangkan oleh Jean Piaget, yaitu tahap sensorimotor, tahap pra-operasional, tahap operasional konkret dan tahap operasional. Berdasarkan observasi yang dilakukan oleh peneliti siswa masi berada pada tahap konkret. Berdasarkan tahapan usia menurut Jean Piaget, rata-rata usia anak sekolah dasar yaitu 6-12 tahun, diman pada usia tersebut anak berada pada masa operasional konkret. Maka kehadiran media sangat penting untuk menunjang siswa dalam proses belajar, khususnya untuk dapat membaca.

\section{Perencanaan (design)}

Tahap perencanaan pada penelitian ini merupakan tahap dimana peneliti membuat desain media pop-up book . berikut adalah langkanlangkah yang dilakukan dalam mendesain media pop-up book:

\section{Tampilan luar (Cover)}

Desain tampilan luar (cover) di sesuaikan dengan materi yang di gunakan serta karakteristik siswa. Dengan gambar yang di buat gradasi dan teks yang kontras dengan gambar latar belakangnya. Bahan cover yang digunakan tebal dengan finishing laminasi agar tahan lama, dan juga membuat kesan dari cover nya sendiri lebih terlihat bagus

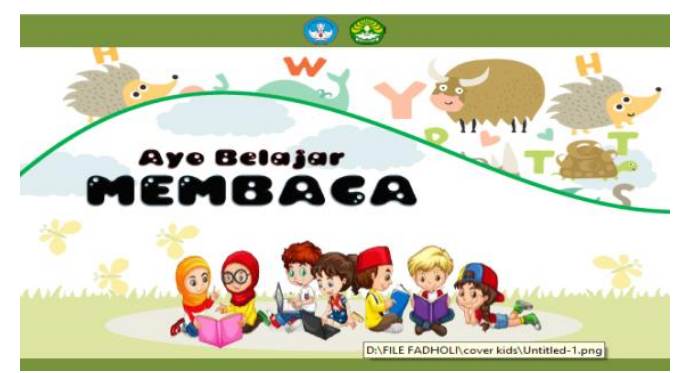

Gambar 1. Sampul Depan Media

\section{b. Gambar dan warna}

Penggunaan warna yang sesuai dapat membangkitkan motivasi, perhatian, perasaan, serta kesedian siswa sendiri untuk belajar. Disini peneliti menggunakan warna-warna yang kuat sehingga dapat lebih membuat warna pada media yang di kembangkan dapat menonjol dari unsur lain yang terdapat di dalam media. Pemilihan warna dalam media tersebut di sesuaikan dengan karakteristik siswa. 

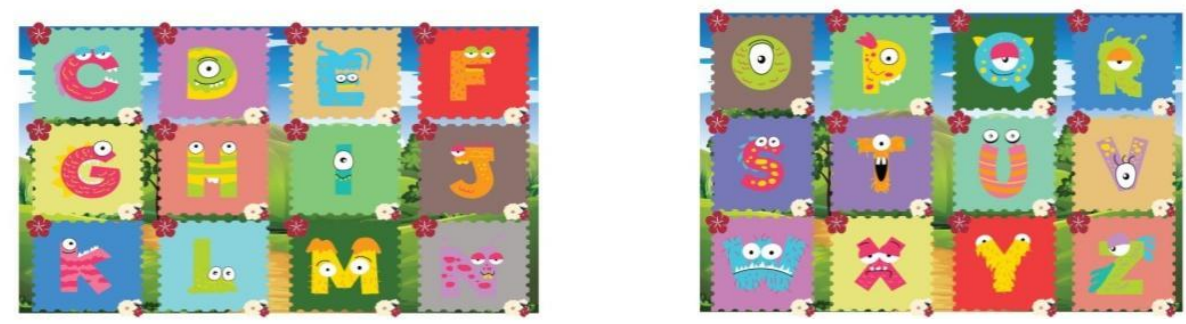

Gambar 2. Penggunaan Warna Yang Beragam

Gambar yang digunakan dalam media pop-up book ini adalah gambar yang umumnya berada di sekitar siswa. Sehingga siswa dapat dengan mudah mengenal gambar tersebut. Slide pada pop-up book dapat dilihat pada gambar di bawah ini :
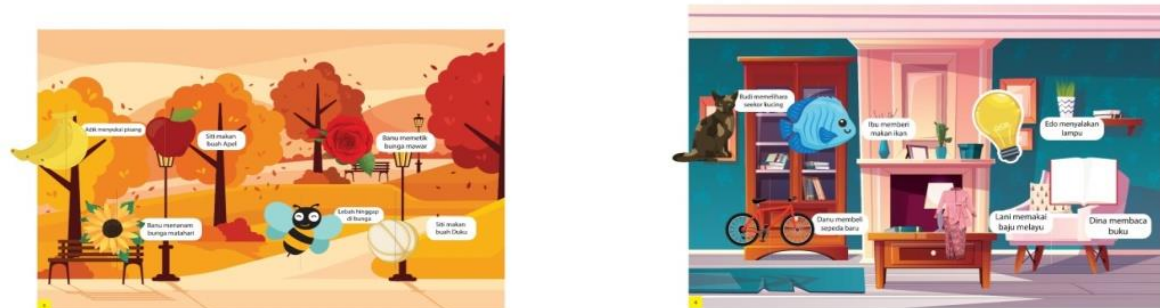

Gambar 3. Di Gunakan Adalah Gambar Yang Berada Di Sekitar Siswa

\section{a. Konten atau materi}

Isi materi yang di muat dalam media popup book, berupa abjad, kata yang di sertai dengan gambar yang berhubungan dengan kata tersebut, serta kalimat pendek yang di susun atau di buat

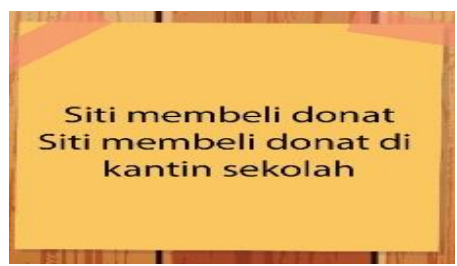

berdasarkan penulisan kalimat yang di sesuaikan dengan SPO dan SPOK yang terlebih dahulu di validasi oleh ahli materi sebelum di masukan ke dalam media Pop-up book.

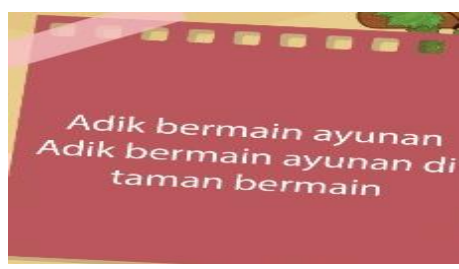

Gambar 4. Materi SPOK Yang Dimasukan Ke Dalam Media 


\section{Pengembangan (Development)}

Tahap pengembangan terdiri atas pembuatan media, validasi oleh validator. Langkah yang dilakukan membuat desain media menggunakan software adobe photoshop CS3 berdasarkan materi yang dipilih. Kertas yang digunakan adalah kertas artcartoon. Setelah media di print, selanjutnya pemotongan media menggunakan gunting atau cutter kemudian dirakit berdasarkan susunan. di validasi oleh ahli. 1 orang ahli media, 1 orang ahli materi, serta 1 orang ahli lapangan.

Penilaian yang dilakukan oleh validator terhadap produk dilihat dari 5 aspek penilaian yaitu : aspek kesederhanaan, aspek penekanan, aspek keseimbangan, aspek keterpaduan, serta desain media.

a. Validasi ahli media.

Tebel 2. Data Validasi Ahli Media

\begin{tabular}{cclcc}
\hline No & $\begin{array}{c}\text { Aspek } \\
\text { Penilaian }\end{array}$ & $\begin{array}{c}\text { Indikator } \\
\text { Penilaian }\end{array}$ & $\begin{array}{c}\text { Skor } \\
\text { Penilaian }\end{array}$ & $\begin{array}{c}\text { Kategori } \\
\text { Skor }\end{array}$ \\
\hline \multirow{2}{*}{ 1. } & \multirow{2}{*}{ Desain } & Kemenarikan & $87.5 \%$ & $\begin{array}{c}\text { Sangat } \\
\text { Layak }\end{array}$ \\
\cline { 3 - 4 } & media & & $\begin{array}{c}\text { Sangat } \\
\text { Layak }\end{array}$ \\
\cline { 2 - 4 } & Kualitas isi media & $91.6 \%$ & $\begin{array}{c}\text { Sangat } \\
\text { Layak }\end{array}$ \\
\hline & & $\mathbf{8 9 . 5 5 \%}$ & \\
\hline
\end{tabular}

Hasil dari tabel menunjukkan bahwa ratarata skor penilaian pada validasi oleh ahli media dalam Pengembangan media Pop-up Book dalam membaca permulaan di kelas rendah menunjukkan angka $89.55 \%$ dengan kategori Sangat Layak. Aspek desain dengan indikator kemenarikan media memperoleh presentase skor $87.5 \%$ dengan katagori Sangat Layak. Aspek desain dengan indikator kualitas isi media memperoleh presentase skor 91.6\% dengan kategori Sangat Layak.

b. Validasi ahli materi

Tebel 3. Data Validasi Ahli Materi

\begin{tabular}{llcc} 
No & Aspek penilaian & Skor Penilaian & Kategori skor \\
\hline 1 & Kesederhanaan & $87.5 \%$ & Sangat Layak \\
\hline 2 & Penekanan & $91.6 \%$ & Sangat Layak \\
\hline 3 & Keseimbangan & $91.6 \%$ & Sangat Layak \\
\hline 4 & Keterpaduan & $83.3 \%$ & Layak \\
\hline & Rata - rata Skor & $\mathbf{8 8 . 5 \%}$ & Sangat Layak \\
\hline
\end{tabular}

Hasil dari tabel menunjukkan bahwa ratarata skor penilaian pada validasi oleh ahli materi menunjukkan angka $88.5 \%$ dengan kategori Sangat Layak. Aspek kesederhanaan pada aspek ini menunjukkan angka $87.5 \%$ dengan kategori Sangat Layak. Aspek penekanan, pada aspek ini menunjukkan angka 91.6\% dengan katagori Sangat
Layak. Aspek keseimbangan, pada aspek ini menunjukkan angka $91.6 \%$ denga katagori Sangat Layak. Aspek keterpaduan, pada aspek ini menunjukkan angka $83.3 \%$ dengan katagori Layak.

c. Ahli lapangan. 
Jurnal PAJAR (Pendidikan dan Pengajaran)

Volume 5 Nomor 5 September 2021 | ISSN Cetak : 2580 - 8435| |ISSN Online : 2614 - 1337

DOI : http://dx.doi.org/10.33578/pjr.v5i5.8117

Tebel 4. Data Validasi Media

\begin{tabular}{ccccc}
\hline No & Aspek Penilaian & Indikator Penilaian & Skor Penilaian & Kategori Skor \\
\hline \multirow{2}{*}{ 1. } & \multirow{2}{*}{ Desain } & Kemenarikan media & $85 \%$ & Sangat Layak \\
\cline { 3 - 5 } & & & & \\
\cline { 3 - 5 } & & & $87.5 \%$ & Sangatitas isi media \\
\hline & Rata-rata Skor & $\mathbf{8 6 . 2 5 \%}$ & Sangat Layak \\
\hline
\end{tabular}

Hasil dari tabel menunjukkan bahwa ratarata skor penilaian pada validasi oleh ahli lapangan dalam Pengembangan media Pop-up Book dalam membaca permulaan di kelas rendah menunjukkan angka $86.25 \%$ dengan kategori Sangat Layak.
Aspek desain dengan indikator kemenarikan memperoleh presentase skor $85 \%$ dengan katagori Sangat Layak. Aspek desain dengan indikator kualitas isi media memperoleh presentase skor 87.5\% dengan kategori Sangat Layak.

Tabel 5. Data Validasi Pengguna Lapangan (Materi)

\begin{tabular}{llcc}
\hline No & Aspek penilaian & Skor Penilaian & Kategori skor \\
\hline 1 & Kesederhanaan & $87.5 \%$ & Sangat Layak \\
\hline 2 & Penekanan & $75 \%$ & Layak \\
\hline 3 & Keseimbangan & $87.5 \%$ & Sangat Layak \\
\hline 4 & Keterpaduan & $91.6 \%$ & Sangat Layak \\
\hline & Rata - rata Skor & $\mathbf{8 5 . 4 \%}$ & Sangat Layak \\
\hline
\end{tabular}

Hasil dari tabel menunjukkan bahwa ratarata skor penilaian pada validasi oleh pengguna lapangan menunjukkan angka $85.4 \%$ dengan kategori Sangat Layak. Aspek kesederhanaan, memperoleh presentase skor $87.5 \%$ dengan kategori Sangat Layak. Aspek penekanan, memperoleh presentase skor $75 \%$ dengan kategori
Layak. Aspek keseimbangan memperoleh presentase skor $87.5 \%$ dengan kategori Sangat Layak. Aspek keterpaduan, terdapat dalam pengembangan produk. Pada aspek ini memperoleh presentase skor $91.6 \%$ dengan kata gori Sangat Layak.

Tabel 6. Gambar sebelum dan sesudah validasi.

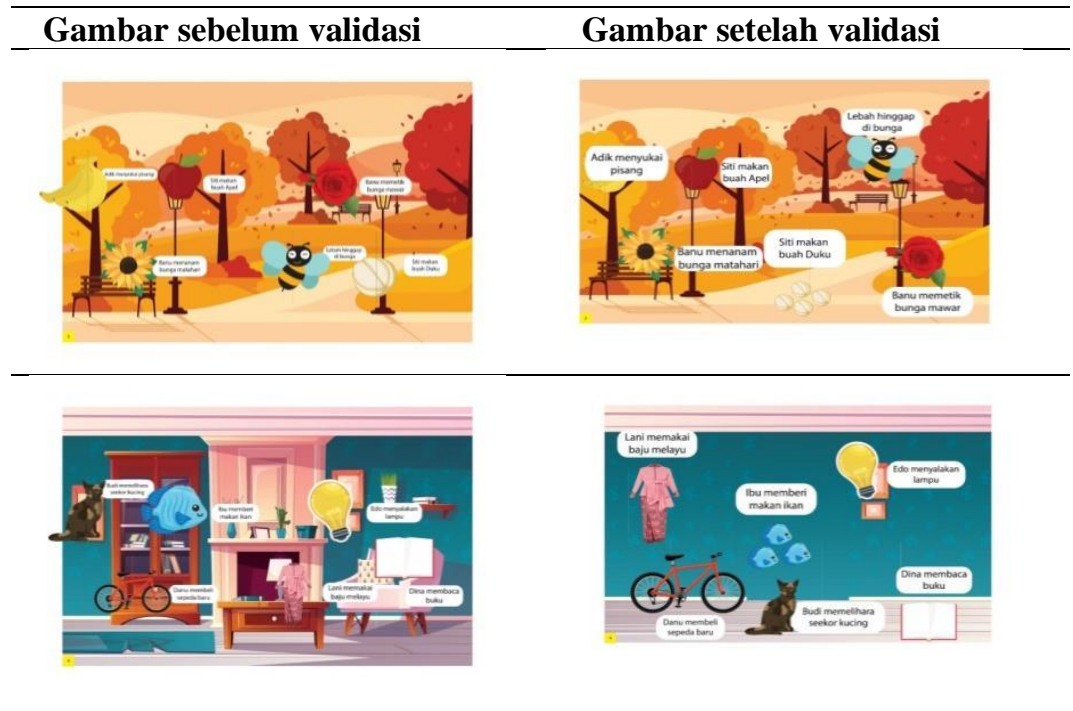



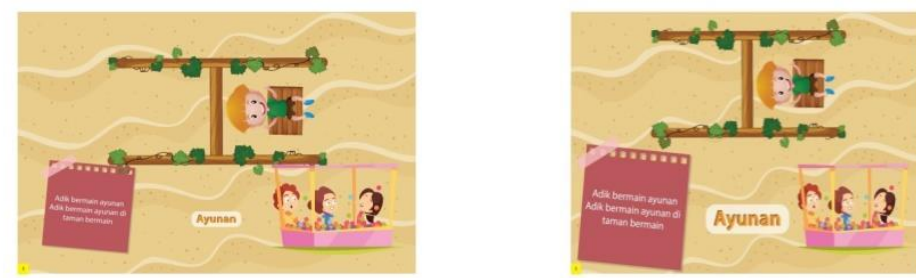

Tujuanya dilakukanya revisi gambar pada Pop-Up Book dalam membaca permulaan di kelas rendah yang peneliti kembangkan untuk siswa kelas rendah sehingga layak untuk digunakan. Perbaikan yang dilakukan pada gambar 1, dimana sebelumnya tulisan yang di muat dalam gambar tersebut terlalu kecil sehingga sagat sulit untuk dapat dibaca. Setelah dilakukanya revisi tulisan pada gambar satu sudah bagus dan dapat dipaca dengan jelas. Pada gambar kedua, dimana sebelumnya background yang digunakan terdapat lemari, kursi, dan meja yang mengganggu gambar sebenarnya. Setelah dilakukannya revisi, bendabenda yang menghalangi tersebut seperti lemari, kursi dan meja dihilangkan sehingga gambar dan tulisan yang ada dapat dilihat dan dibaca dengan jelas. Pada gambar ketiga, tulisan yang digunakan juga terlalu kecil sehingga sult untuk dapat dibaca. Setelah dilakukanya revisi barulah tulisan yang terdapat dalam gambar tersebut dapat di baca dengan jelas.

\section{Implementasi (implementation)}

Pada tahap implementasi, dilakukanlah uji coba terbatas.

* di karenakan keadaan yang tidak memungkinkan. Jadi uji coba terbatas tidak di lakukan.

\section{Evaluasi (evaluation)}

Pada tahap ini penilaian ini telah dilakukan dengan validasi produk oleh beberapa ahli seperti ahli media, ahli materi, serta ahli dilapangan. Sehingga peneliti dapat mengetahui media yang di kembangkan oleh peneliti Sangat Layak di gunakan sebagai media dalam membaca permulaan di kelas rendah.

\section{Pembahasan Hasil Penelitian}

Berdasarkan maksud dan tujuan penelitian ini digolongkan kedalam penelitian pengembangan yaitu penelitian yang bermaksud mengembangankan sebuah produk, dimana produk yang dikembangkan berupa Pegembangan media Pop-Up Book dalam membaca permulaan di kelas rendah. Pegembangan media Pop-Up Book dalam membaca permulaan di kelas rendah ini dilakukan dengan metode Research and Development $(R n D)$ sesuai dengan prosedur pengembangan model EDDIE. Model EDDIE terdiri dari lima tahapan yaitu : 1) Analyze (analisis); 2) Design (perancangan); 3) Development (pengembangan); 4) Implementation (implementasi); 5) Evaluation (penilaian)

Kelayakan media Pop-Up Book diketahui melalui tahap penilaian oleh para ahli. Tim ahli tersebut tersiri dari 3 orang validator yaitu 1 orang validator media, 1 orang validator materi, serta 1 orang validator dilapangan yang merupakan guru kelas II SD. Instrument yang digunakan berupa angket dengan skala 1-4. Berdasarkan hasil validasi kelayakan media Pop-Up Book di tujukan oleh penilaian ahli materi tersebut memperoleh skor presentase $88.55 \%$ dengan kategori Sangat Layak. Penilaian oleh ahli dilapangan dengan aspek desain media memperoleh skor presentase $86.25 \%$ dengan kategori Sangat Layak. Serta penilaian oleh ahli lapangan dalam aspek materi yang terdapat dalam media memperoleh skor presentase $85.4 \%$ dengan kategori Sangat Layak.

Dari hasil validasi kelayakan yang diperoleh dari masing-masing validator dapat dikatakan bahwa media yang di kembangkan yaitu media Pop-Up Book dalam membaca permulaan di kelas rendah. Dapat dikatakan Sangat Layak untuk di jadikan sebuah media dalam membaca permulaan di kelas rendah.

\section{SIMPULAN DAN REKOMENDASI}

Berdasarkan hasil penelitian yang dilakukan maka dapat disimpulkan bahwa: 
1. Media Pop-Up Book dalam membaca permulaan di kelas rendah berhasil di kembangkan menggunakan pendekatan Research and Development (R\&D) dengan model EDDIE.

2. Pada uji kelayakan media Pop-Up Book pendapatkan skor presentase, yaitu oleh ahli media memperoleh presentase $89.55 \%$ dengan kategori Sangat Layak. Oleh ahli materi memperoleh presentase $88.55 \%$ dengan kategori Sangat Layak. Dan oleh ahli di lapangan memperoleh presentase $86.25 \%$ dengan kategori Sangat Layak (desain media), dan juga memperoleh presentase 85.4\% dengan kategori Sangat Layak (materi dalam media).

Dengan demikian, dapat disimpulkan bahwa media Pop-Up Book dalam membaca permulaan di kelas rendah layak serta dapat digunakan.

Bagi peneliti selanjutnya perlu dilakukan penelitian lebih lanjut untuk memperoleh data, masukan dan saran yang lebih banyak lagi agar media Pop-Up Book yang di kembangkan lebih maksimal, serta perlu melakukan uji coba secara luas.

\section{DAFTAR PUSTAKA}

Arsyad, A. (2011). Media Pembelajaran . Jakarta: PT RAJAGRAFINDO PERSADA.

Irdawati. (2016). Meningkatkan Kemampuan Membaca Permulaan Dengan Media Di Kelas I.

Rahmatilah, S. (2017). Media Buku Pop-Up Untuk Pembelajaran Bahasa Indonesia Di Kelas Rendah.

Rosalina, C. D. (2018). Pengembangan Media Buku Pop-Up Untuk Pembelajaran Mengenak Huruf Alphabet Anak Usia Dini.

Aadiman, A. S. (2011). Media Pendidikan: pengertian, pengembangan dan pemanfaatanya. jakarta: PT RAJA GRAFINDO PERSADA.

Sholikhah, A. (2017). Pengembangan Media Pop Up Book Untuk Meningkatkan Kemampuan Menulis Kreatif Pada Mata Pelajaran Bahasa Indonesia.
Sugiyono. (2017). METODE PENELITIAN : Kualitatif, Kuantitaif, dan RnD. Bandung: Alfabeta.

Sukiman. (2012). Pengembangan Media Pembelajaran. Ygyakarta: PT Pustaka Insan Madani.

Taufina. (2016). Mozaik Keterampilan Berbahasa Di Sekolah Dasar. Bandung: CV. Angkasa.

Wahyudi, F. A. (2017). Pengembangan Buku PopUp Tiga Dimensi Sebagai Media Pembelajaran Menulis Puisi. 